\title{
Morphology Variation of Macrobrachium lar (Fabricius, 1798) occuring in Rivers of Manokwari, West Papua, Indonesia
}

\author{
Ahmad Fadli, Robi Binur, Elda Irma Jeanne Joice Kawulur* \\ Department of Biology, Faculty of Mathematics and Natural Sciences, University of Papua, Jalan Gunung Salju Amban Manokwari,
} Papua, Indonesia

ARTICLE INFO

Article history:

Received February 8, 2017

Received in revised form November 3, 2017

Accepted November 30, 2017

KEYWORDS:

morphometric,

meristic,

Macrobrachium lar,

river,

manokwari

\begin{abstract}
Morphology character is the result of interaction between genetic and environmental factor, and the last factor is the dominant factor of variation. Morphometric character of shrimp is required to determine the value of portion of body part that can be consumed, so that it can be used as baseline in designing breeding program. This research aimed to study the variation of morphometric and meristic of Macrobrachium lar population from several rivers i.e. Andai, Wariori, Muara Prafi and Pami, in Manokwari West Papua Province. We found eight morphometric characters which were significanly different $(\mathbf{p}<0.01)$ among lar shrimp populations. Among the eight characters, there were three best morphometric characters, body weight (BT), total length (PT), and rostrum length (PR) that could be used for determining the differences between populations. Total number of upper teeth rostrum ranged between 7-9, while lower teeth ranged between 0-5. The meristic characters between populations were not significanlly different $(p>0.05)$. Morphometric characters of Andai and Pami population tended to similar each other as well as those of Wariori and Muara Prafi population. It showed that the similarity of the characters might related to close distance of the rivers. Although the four those rivers came from different upstream source, the closer distance of the M. lar population, the closer genetic relationship of $M$. lar population.
\end{abstract}

\section{Introduction}

Indonesia has various species of freshwater shrimp which are potential to be develop. Macrobrachium lar (Palaemonidae family), or commonly known as monkey river prawn, is freshwater shrimp which spread naturally in Indonesia including Papua region. This shrimp have lage size (adult shrimp > $140 \mathrm{~mm}$ ), fast growth relativelly, and good taste (Lal et al. 2014).

Macrobrachium lar is commonly sold by local people in Manokwari at traditional market. The price is quite high, which is around IRD. 40,000-80,000/ $\mathrm{kg}$. The continuous chatching will result the decline of this shrimp population in nature (Nandlal 2005; Fauzi 2013). Therefore, conservation efforts need to be undertaken by first examining the aspects relating to these shrimp.

The information of $M$. lar is still less well known. However some the studies have undertaken, although

* Corresponding Author.

E-mail Address: irmakawulur@yahoo.com only on limited fields such as on biology and taxonomy (Riek 1951; Short 2004; Nandlal 2005; Sethi et al. 2013b), reproduction (Lal et al. 2014), and food (Sethi et al. 2013a). The study of morphometric character of a population is very important, because such study intend to determine the value of the portion of the body part that can be consumed so that it can be used as baseline in designing breeding program (Wahidah et al. 2017).

Morphometric character of a population is the result of interaction between the genetic and environment factors. The geographical condition of Manokwari varies widely, ranging from coastal, lowlands, highlands to mountains. Thus geographical variations resulted formation of several watersheds (DAS) in this region. The geographical location, springs, flow direction and vegetation conditions along the rivers could caused the morphology variation of $M$. lar This research aimed to figure out the morphometic characters of M. lar from four rivers in Manokwari. 


\section{Materials and Methods}

This research was conducted from December 2014 to January 2015. The research sites were located on Andai River, Wariori River, Muara Prafi River and Pami River, in Manokwari, West Papua Province. At each site, 20 samples of adult size of M. lar were collected. Measurement of morphometric and meristic characters were performed at Zoology Laboratory of Biology Department FMIPA University of Papua.

The morphological character observation was conducted based on observation method of Munasinghe and Thusari (2010). 11 morphometric characters and two meristic characters were measured i.e weight (gr), total length $(\mathrm{mm})$, abdominal length $(\mathrm{mm})$, telson length $(\mathrm{mm})$, carapace length $(\mathrm{mm})$, carapace widht, carapace diagonal length $(\mathrm{mm})$, rostrum length $(\mathrm{mm})$, first abdominal length $(\mathrm{mm})$, first abdominal widht ( $\mathrm{mm}$ ), second abdominal length (mm), upper and lower teeth rostrum. Measurements of length, width and body weight of morphometric shrimp were performed using digital veener calliper with $0.01 \mathrm{~mm}$ accuracy level, while the observation of meristic character was done by counting the number of rostrum teeth. Symbol and definiton of morphological characteristics were presented in Table 1.

\subsection{Data Analysis}

Analysis of morphology variation were done based on morphometric dan meristic character. Mean and standard deviation were analyzed descriptively. Difference of morphometric character of $M$. lar were analyzed using One Way Analysis of Variance (ANOVA) and Duncan (DMRT) test. In order to finding the best character in characterizing differences among populations Analysis Principal Component Analysis (PCA) were used. All analysis were performed using R program version 3.1.2 (R Development Core Team 2014) and SPSS 19.0 version. Before all characters analyzed statistically, data measurement of morphometric character was standardized through regression analysis, that is length of carapace as standard length (independent) and ten other morphometric parameter as character influenced by carapace length (dependent) (Munasinghe and Thusari 2010).

\section{Results}

The sample of M. lar were collected from four locations: Sungai Andai, Sungai Wariori, Sungai Muara Prafi and Sungai Pami. Each location was collected 20 samples. Total number of $M$. lar were 80 samples. The total length of $M$. lar ranged 92.67-142.27 mm and the body weight ranged $12.50-47.70 \mathrm{~g}$.

Table 2 showed statistic analysis of 11 morphome tric analysis of $M$. lar using ANOVA test. The result showed that eight character morphometric of M. lar (body weight/BT, total length/PT, abdomen length/ $\mathrm{PAb}$, telson length/PTel, rostrum length/PR, first abdomen length /1PAp, first abdomen widht/LAP and second abdomen length/2PAk) interpopulation were significantly different $(p<0.05)$, while carapace length (PK), carapace widht (LK) and carapace diagonal length (PDK) were not showed the different. Based on DMRT test result at $\mathrm{p}<0.05$ showed that M. lar population from Andai river differ to Wariori river. The three character of carapace (PK, LK, and PDK) were not showed the differences interpopulation.

Eight morphometric characters which found significantly different according to ANOVA test then continues to analyze using PCA analysis for finding the best character morphometric in characterizing differences inter population of M. lar. Table 3 showed that three components (PC) be able to inform $99.22 \%$ of morphometric characters of $M$. lar which were significantly different (BT, PT, Pab, PTel, PR, 1PAp, LAP, and 2PAk). The first component (PC1) was able to explain $91.66 \%$ of these characters.

Table 1. Symbol, characteristic, and definition of morphology character of M. lar

\begin{tabular}{|c|c|c|}
\hline Morphometric character & Symbol & Definition of characteristic \\
\hline Body weight & BT & Body weight in fresh \\
\hline Total length & PT & $\begin{array}{l}\text { The distance between the tip of the rostrum and the tip of } \\
\text { the telson }\end{array}$ \\
\hline Abdomen length & Pab & $\begin{array}{l}\text { The distance between the first segment and the tip of the } \\
\text { telson }\end{array}$ \\
\hline Telson length & Ptel & The maximum length of the telson \\
\hline Carapace length & PK & $\begin{array}{l}\text { The distance between the eye and the base of the } \\
\text { carapace }\end{array}$ \\
\hline Carapace widht & LK & The maximum widht of the carapace \\
\hline Carapace diagonal length & PDL & $\begin{array}{l}\text { The distance between the base of the eye and the base of } \\
\text { lower carapace }\end{array}$ \\
\hline Rostrum length & PR & $\begin{array}{l}\text { The distance between the tip of the rostrum and the base } \\
\text { of the rostrum }\end{array}$ \\
\hline First abdominal length & 1Pap & The maximum length of the first abdominal \\
\hline First abdominal widht & LAP & The maximum widht of the first abdominal \\
\hline Second abdominal length & 2Pak & The maximum length of the second abdominal \\
\hline
\end{tabular}


Table 2. Statistic analysis result of morphometric characters of M. lar (ANOVA \& DMRT)

\begin{tabular}{|c|c|c|c|c|}
\hline Morphometric Character & Location & Mean & Standart Deviation (SD) & Significancy ( $p$ value) \\
\hline \multirow[t]{4}{*}{ Body weight (gr) } & Andai & $18.67^{\mathrm{a}}$ & 4.47 & \multirow[t]{4}{*}{$0.002^{*}$} \\
\hline & Wariori & $27.07^{\mathrm{b}}$ & 12.69 & \\
\hline & Muara Prafi & $20.07^{\mathrm{a}}$ & 5.37 & \\
\hline & Pami & $27.36^{\mathrm{b}}$ & 9.62 & \\
\hline \multirow[t]{4}{*}{ Total Length (mm) } & Andai & $105.59^{a}$ & 6.21 & \multirow[t]{4}{*}{$0.000^{*}$} \\
\hline & Wariori & $120.26^{c}$ & 15.19 & \\
\hline & Muara Prafi & $115.39^{b c}$ & 7.85 & \\
\hline & Pami & $110.74^{\mathrm{ab}}$ & 10.77 & \\
\hline \multirow[t]{4}{*}{ Abdomen Length (mm) } & Andai & $57.92^{\mathrm{a}}$ & 3.14 & \multirow[t]{4}{*}{$0.000^{*}$} \\
\hline & Wariori & $65.43^{\mathrm{b}}$ & 7.63 & \\
\hline & Muara Prafi & $62.29^{\mathrm{b}}$ & 3.84 & \\
\hline & Pami & $62.50^{\mathrm{b}}$ & 4.97 & \\
\hline \multirow[t]{4}{*}{ Telson Length (mm) } & Andai & $13.61^{\mathrm{a}}$ & 1.09 & \multirow[t]{4}{*}{$0.016^{*}$} \\
\hline & Wariori & $15.14^{\mathrm{b}}$ & 2.19 & \\
\hline & Muara Prafi & $14.56^{\mathrm{ab}}$ & 0.97 & \\
\hline & Pami & $14.79^{b}$ & 1.56 & \\
\hline \multirow[t]{4}{*}{ Carapace Length (mm) } & Andai & $36.30^{a}$ & 2.66 & \multirow[t]{4}{*}{0.162} \\
\hline & Wariori & $38.79^{a}$ & 6.59 & \\
\hline & Muara Prafi & $35.80^{\mathrm{a}}$ & 3.04 & \\
\hline & Pami & $37.78^{a}$ & 5.04 & \\
\hline \multirow{4}{*}{ Carapace Widht (mm) } & Andai & $17.64^{\mathrm{a}}$ & 1.72 & \multirow{4}{*}{0.151} \\
\hline & Wariori & $18,54^{\mathrm{a}}$ & 3.14 & \\
\hline & Muara Prafi & $17.97^{\mathrm{a}}$ & 1.57 & \\
\hline & Pami & $19.16^{\mathrm{a}}$ & 2.11 & \\
\hline \multirow{4}{*}{$\begin{array}{l}\text { Carapace Diagonal Length } \\
(\mathrm{mm})\end{array}$} & Andai & $35.13^{a}$ & 2.82 & \multirow[t]{4}{*}{0.185} \\
\hline & Wariori & $37.40^{\mathrm{a}}$ & 6.49 & \\
\hline & Muara Prafi & $34.60^{\mathrm{a}}$ & 3.10 & \\
\hline & Pami & $36.85^{\mathrm{a}}$ & 5.24 & \\
\hline \multirow[t]{4}{*}{ Rostrum Length (mm) } & Andai & $27.06^{a}$ & 2.03 & \multirow[t]{4}{*}{$0.000^{*}$} \\
\hline & Wariori & $32.48^{\mathrm{b}}$ & 4.72 & \\
\hline & Muara Prafi & $32.35^{\mathrm{b}}$ & 2.96 & \\
\hline & Pami & $27.11^{\mathrm{a}}$ & 3.56 & \\
\hline \multirow{4}{*}{$\begin{array}{l}\text { First Abdominal Length } \\
(\mathrm{mm})\end{array}$} & Andai & $5.35^{\mathrm{a}}$ & 0.41 & \multirow{4}{*}{$0.002^{*}$} \\
\hline & Wariori & $6.09^{\mathrm{b}}$ & 0.87 & \\
\hline & Muara Prafi & $5.70^{\mathrm{ab}}$ & 0.43 & \\
\hline & Pami & $5.85^{\mathrm{b}}$ & 0.53 & \\
\hline \multirow{4}{*}{$\begin{array}{l}\text { First Abdominal Widht } \\
(\mathrm{mm})\end{array}$} & Andai & $16.23^{\mathrm{a}}$ & 1.26 & \multirow{4}{*}{$0.006^{*}$} \\
\hline & Wariori & $17.87^{b}$ & 2.00 & \\
\hline & Muara Prafi & $17.01^{\mathrm{ab}}$ & 1.21 & \\
\hline & Pami & $17.01^{\mathrm{ab}}$ & 0.98 & \\
\hline \multirow{4}{*}{$\begin{array}{l}\text { Second Abdominal Length } \\
(\mathrm{mm})\end{array}$} & Andai & $8.55^{\mathrm{a}}$ & 0.49 & \multirow[t]{4}{*}{$0.000^{*}$} \\
\hline & Wariori & $9.80^{\mathrm{bc}}$ & 1.04 & \\
\hline & Muara Prafi & $9.45^{\mathrm{b}}$ & 0.67 & \\
\hline & Pami & $10.14^{\mathrm{c}}$ & 0.77 & \\
\hline
\end{tabular}
the same subset alphabet (a,b,or c), indicates not significantly different according to DMRT at $p<0.05$

Table 3. PC1, PC2, and PC3 of eight characters morphemetric M. lar

\begin{tabular}{lccc}
\hline Morphemetric character & PC1 & PC2 & PC3 \\
\hline Body weight (BT) & $-0.54441604^{*}$ & $0.773251974^{*}$ & $0.30534756^{*}$ \\
Total Length (PT) & $-0.71646701^{*}$ & $-0.441143742^{*}$ & -0.04010509 \\
Abdominal Length (PAb) & $-0.34805244^{*}$ & -0.013290474 & $-0.67104710^{*}$ \\
Telson Length (PTel) & -0.09456418 & 0.009294044 & -0.01009236 \\
Rostrum Length (PR) & $-0.22900599^{*}$ & $-0.452061793^{*}$ & $0.56056243^{*}$ \\
First Abdominal Length (1PAp) & -0.03667661 & 0.010653727 & -0.04182585 \\
First Abdominal Widht (LAP) & -0.06786950 & -0.003598693 & $-0.32031969 *$ \\
Second Abdominal Length (2PAk) & -0.04252209 & 0.052194351 & $-0.19016848^{*}$ \\
\hline Standart Deviation & 16.1362 & 4.30903 & 1.7025 \\
Varians Proportion & $91.66 \%$ & $6.54 \%$ & $1.02 \%$ \\
Accumulation Proportion & $91.66 \%$ & $98.20 \%$ & $99.22 \%$ \\
\hline
\end{tabular}

* the value of charater $\geq 0.1$ 
PC1 showed the value with the same direction of all morphometric characters, while in PC2 the value of BT, PTel, 1PAp, and 2PAk contrast with the value of PT, PAb, PR and LAP. It means, according to PC2 if the values of BT, PTel, 1PAp, and 2Pak increased, so the values of PT, PAb, PR, and LAP decreased. In PC3, the values of BT and PR were contrast with the other character values. Therefore, three character morphometrics (body weight/BT, total length/PT and rostrum length/PR) were the best morphometric characters for characterizing the differences among $M$. lar populations, because the variation proportion of PC1 (91.66\%) and PC2 $(6.54 \%)$ is greater than PC3 $(1.02 \%)$. Thus, the characters with the greatest value $\geq 0.1$ in PC1 and PC2 were strongly influence the differences among M. lar populations.

Figure 1 showed the cluster of four groups of M. lar based on the first component (PC1) and the second component (PC2). However, some individuals appeared to interconnected between populations. Wariori population had a wide distribution, but more interconnected to the Muara Prafi population compared with Andai population. Meanwhile, the Pami population only interconnected with Andai population. Thus the morphometric characters of the $M$. lar from Wariori River were more similar to the Muara Prafi River, whereas M. lar population of the Pami River were more similar to Andai River.

The M. lar meristic had upper teeth rostrum $(\mathrm{NaR})$ ranging between 7-9 and lower teeth rostrum (NbR) ranging between 0-5 (Table 4). Table 4 showed the range of upper teeth rostrum of the shrimps from Andai River population were different from the other three populations. While based on the range of lower teeth rostrum of the population of Muara Prafi and Pami were different from those of Andai and Wariori. The result of Kruskal-Wallis test in Table 5 showed that there were not significantly different $(p>0.05)$ on the meristic character among $M$. lar population.

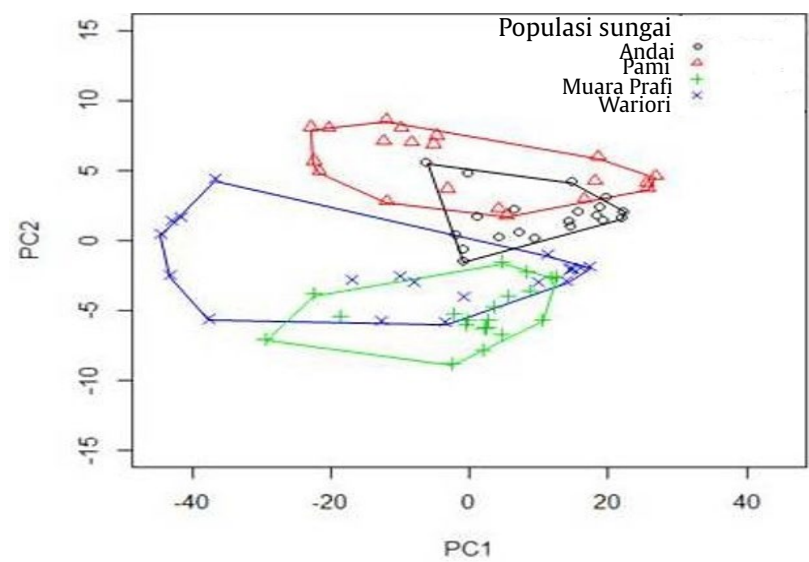

Figure 1. Scatterplot PC1 and PC2 of eight morphometric characters (BT, PT, PAb, PTel, PR, 1PAp, LAP, and 2Pak) of M. lar
Table 4. Total number of meristic character of $M$. lar in four location

\begin{tabular}{lcc}
\hline \multirow{2}{*}{ Location } & \multicolumn{2}{c}{ Meristic character range } \\
\cline { 2 - 3 } & $\begin{array}{l}\text { Total number upper } \\
\text { teeth rostrum (NaR) }\end{array}$ & $\begin{array}{c}\text { Total number lower } \\
\text { eeth Rostrum (NbR) }\end{array}$ \\
\hline Andai & $8-9$ & $1-5$ \\
Wariori & $7-9$ & $0-3$ \\
Muara Prafi & $7-9$ & $2-3$ \\
Pami & $7-9$ & $2-3$ \\
\hline
\end{tabular}

Table 5. Kruskal-Wallis test of meristic characters of M. lar

\begin{tabular}{lcc}
\hline \multirow{2}{*}{ Location } & \multicolumn{2}{c}{ Meristic character range } \\
\cline { 2 - 3 } & $\begin{array}{l}\text { Total number upper } \\
\text { teeth rostrum (NaR) }\end{array}$ & $\begin{array}{c}\text { Total number lower } \\
\text { eeth Rostrum (NbR) }\end{array}$ \\
\hline Andai & 45.28 & 46.80 \\
Wariori & 41.00 & 37.10 \\
Muara Prafi & 42.03 & 38.10 \\
Pami & 33.70 & 40.00 \\
\hline p-value & 0.305 & 0.440 \\
\hline
\end{tabular}

\section{Discussion}

M. lar in Manokwari rivers varied in morphometric characters. We found three morphometric characters (body weight/BT, total length/PT and rostrum length/PR) which were the best and could be used for characterizing the differences among $M$. lar populations. It was caused by the variation proportion of PC1 (91.66\%) and PC2 (6.54\%) which were greater than PC3 (1.02\%), so that the character with the greatest value $(\geq 0.1)$ in PC1 and PC2 were strongly influence the differences between $M$. lar population. Therefore, the three characters have been able to represent other characters in showing the differences in morphometric characters among $M$. lar population. Sethi et al. (2013) also explained that morphometric characters of M. lar in Andaman island varied between sex. Correlation analysis between the morphometric characters showed that the total length (PT) was significantly correlated with telson length (PTel), whereas body weight (BT) was correlated with carapace length (PK), carapace width (LK), abdomen length $(\mathrm{PAb})$, and while rostrum length (PR) was not correlated with the other characters. Other shrimp in South Sulawesi, M. rosenbergii, which is closed relationship with $M$. lar, also showed having the variation of morphometric characters in three locations (Wahidah et al. 2017).

Upper teeth rostrum (NaR) of $M$. lar ranged between 7-9 and lower teeth rostrum (NbR) ranged between $0-5$. Total number of rostrum teeth in this study were still relatively within the range of study of Short (2004) which stated that $M$. lars have 7-9 teeth on the top (dorsal) and 2-4 teeth on the bottom (ventral). Munasinghe and Thusari (2010) reported that meristic characters can not be used to indicatethe differences between populations of Macrobrachium rosenbergii prawns. So it can be said that the meristic character 
is a trait which was not influenced by geographical differences and environmental conditions. Thus meristic characters of rostrum characteristics can be used as a tool for identifying and for differentiating M. lar with other freshwater prawns (Palaemonidae Family) as well as giant prawns (New 2002).

Morphometric differences among populations with different geographies can be caused by differences of genetic structure and environmental conditions. Between the two, the enviromental conditions were the dominant factor affected morphology variations. The presence of morphometric characters that have the same value indicated the occurrence of mixing between populations or the traits were maintained when a gene flow occurs. Thus it can be said that the Carapace Length (PK), Carapace Widht (LK), and Carapace Diagonal Length (PDK) were the traits maintained by $M$. lar, while other morphometric characters (BT, PT, Pab, PTel, PR, 1PAp, LAP, and 2PAk) were affected by geographical differences and environmental conditions of $M$. lar habitats (Kusrini et al. 2009; Munasinghe and Thusari 2010). Trijoko et al. (2013) reported water quality, substrate structure, and food composition were the environment condition which could affected adaptation morphology of shrimp.

Based on cluster analysis, M. lar population from Wariori dan Muara Pami tended to similar each other, while M. lar population from Andai and Pami also tended to similar. The similarity of morphometric characters between those rivers might be related to the closer distance between Wariori and Muara Pami, as well as between Andai and Pami. Wariori is the longest river among other rivers and the river upstream comes from Arfak mountain, while the upstream of the three other rivers come from different source. Although the four those rivers come from different upstream source, the $M$. lar population which had closer distance to each other, might have a closer relationship genetically compared to the M. lar population coming from the remote river.

We conclude that $M$. lar in the rivers area of Manokwari have difference of morphometric characters based on the differences of geography. The three morphometric characters (body weight/BT, total length/PT, and rostrum length/PR) were determine the differences between populations. The cluster of M. lar population shows that morphometric of M. lar from Andai and Pami relatively different with Wariori and Prafi.

\section{References}

Fauzi A. 2013. Studi MorfologiUdang Galah (Macrobrachium rosenbergii) di Aliran Sungai Musi, Sumatera Selatan. [Skripsi]. Bogor: Departemen Manajemen Sumberdaya Perairan, Fakultas Perikanan dan Ilmu Kelautan, Institut Pertanian Bogor.

Kusrini E et al. 2009. Studi Morfometrik Udang Jerbung (Fenneropenaeus merguiensis de Man) dari Beberapa Populasi di Perairan Indonesia.JRis Akuakultur 4:15-21.

Lal MM et al. 2014. Complete Larval Development of The Monkey River Prawn Macrobrachium lar (Palaemonidae)Using a Novel Green Water Technique. SpringerPlus 3(568):1-13.

Munasinghe DHN, Thusari GGN. 2010. Analysis of morphological variation of four population of Macrobrachium rosenbergii (De Man, 1879) (Crustacean: Decapoda) in Sri Lanka. Ceylon Journal Science (Biological Science) 39(1):53-60.

Nandlal S. 2005. Monoculture of The Native Freshwater Prawn Macrobrachium lar in Vanatu and Integrated with Taro in Wallis and Futuna. New Caledonia: Secretariat of the Pacific Community.

New MB. 2002. Farming freshwater prawns: A manual for the culture of the Giant River Prawn (Macrobrachium rosenbergii).United Kingdom: FAO Fisheries Technical Paper.

R Development Core Team. 2014. R: A language and environment for statistical computing. Vienna: $R$ Fondation for statistical computing.

Riek EF. 1951. The Australian freshwater prawns of the Family Palaemonidae. Records of the Australian Museum 22(4):358-367.

Sethi SN et al. 2013a. Food and feeding habits of Macrobrachium lar (Decapoda, Palaemonidae) from Andaman and Nicobar islands, India. India J Fish 60(4):131-135.

Sethi SN et al.2013b. Morphometric Relationships of The Monkey River Prawn Macrobrachium lar (Fabricius, 1798)(Decapoda, Palaemonidae) from The Andaman Islands. Indian J Fish 60(2):157-161.

ShortJW.2004. Taxonomic Revision: A Revision of Australian River Prawns, Macrobrachium (Crustacea: Decapoda: Palaemonidae). Hydrobiologia 525:1-100.

Trijoko NSN et al.2013. Karaterisasi morfologi dan diversitas genetik hasil persilangan Macrobrachium rosenbergii pouplasi Samos, Bone, dan Sintetis.J Sain Veteriner 21(2):227-242.

Wahidahetal. 2017.Themorphological characteristics of South Sulawesi's giant freshwater prawn Macrobrachium rosenbergii. AACL Bioflux 10(4):820-829. 